adequate for the scientific community should be adequate for the private sector. Why should you treat the private sector differently?" Dr Sheldon Krimsky, acting director of the promental Policy at Tufts Medical School and a member of the RAC, asked the committee last week.

The committee voted nine to six to support mandatory compliance by nonNIH institutions with the NIH guidelines covering recombinant DNA research. Six members of the committee abstained-NIH Director Dr Donald Frederickson, when appointing individuals to the committee, had made it clear that he expected them to abstain from votes where they might have a conflict of interest (for example, where a scientist was a consultant or a stockholder in a company that might be affected by a RAC decision).

The committee also decided to set up a working party to study containment requirements and related issues for large-scale experiments which would involve both committee members and outside consultants, possibly including trade union representatives. Mr Peter Libassi, General Counsel at the Department of Health, Education and Welfare, met public interest and industry representatives last week to discuss new proposals which the NIH has put forward on how the RAC could guarantee the confidentiality of information which companies would be required to provide in seeking approval for certain types of experiment.

Mr Libassi told both groups that the DHEW will shortly publish in the Federal Register the details of thê ways in which NIH will register companies on the basis of voluntary compliance with the guidelines. Industry is keen to support such a procedure as an alternative to the regulation of research by the Food and Drug Administration.

However, the public interest groups gramme in Urban, Social and Environ-

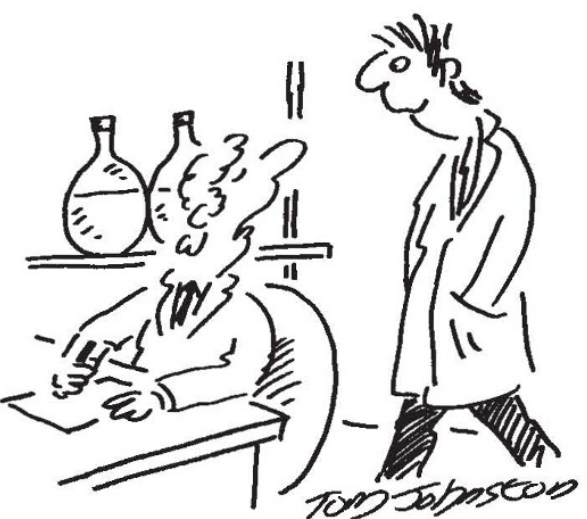

"I'm trying to evolve some guidelines that are as weak as we hope our bacteria are!"

at the meeting made it clear that, given the experience of voluntary requirements in other fields such as toxic waste disposal, they felt it unlikely that voluntary compliance would work adequately. Mr Libassi was told that these groups supported legallybacked requirements as recommended by the RAC.

Meanwhile in California, where a number of small companies are now moving rapidly towards large-scale experiments of possible industrial applications of recombinant DNA research, various state legislators, environmentalists and labour representatives have expressed concern over the possible health hazards to workers. The Chairman of the San Mateo Central Labour Council has written to members of the RAC claiming that current federal efforts that rely on voluntary compliance by industry "are no longer adequate to protect the health and safety of recombinant DNA laboratory workers and other Bay Area cities."

Similarly state senator Barry Keene has urged the RAC to deal directly with the "major policy issues posed by increasing industrial development of this new technology". He wants the state to set up a panel of scientists and lay people to study the issue in California.

David Dickson

\section{Industry spends more on research}

Private companies in the US are expecting the total amount of money spent on research and development to be about $13 \%$ higher in 1979 than in 1978 , according to a survey published last week in New York by McGrawHill Publications. Replies from over 500 companies indicated that the total expenditure on $R$ and $D$ would reach $\$ 40,000$ million, $\$ 4,600$ million more than 1978. Allowing for inflation, this means a real increase of $4.6 \%$.

However the amount of money spent on $\mathbf{R}$ and $\mathbf{D}$ has declined as a proportion of manufacturing sales, from a peak of $3 \%$ in the early 1960 s to just over $2 \%$. Over a fifth of research was 0028-0836/79/0279-0361 \$01.00 engineers are expected to expand in 1980 , particularly in industry.
Northern hemisphere observatory agreement signed in Canary Islands

LAST weekend, Sweden, Denmark and the UK finally signed an intergovernmental agreement with Spain to cooperate over the building of a major observatory at La Palma in the Canary Islands. When it is fully operational (in 1984 at the earliest), the observatory will provide British astronomers with facilities for observing the northern sky equivalent to those at the AngloAustralian telescope in the southern hemisphere. According to Professor F. Graham Smith, director of the Royal Greenwich Observatory, telescopes at the new observatory could compete in terms of image quality with larger telescopes in the US and Soviet Union, because of the particularly fine seeing conditions at the site.

The UK has been planning to build a 'northern hemisphere observatory' for some years. The Canary Island site was decided on, but progress has been slow because of the long time taken by the Spanish Council of Ministers to put its signature to the intergovernmental agreement. The agreement allows for cooperation in astrophysics and states that Spain will provide the site and facilities in return for some of the telescopes' time and training for Spanish astronomers.

Of the four participating countries, the UK is making the biggest contribution. It is building a new $1 \mathrm{~m}$ diameter telescope and is planning to move the $2.5 \mathrm{~m}$ Isaac Newton telescope (INT) from the RGO to the Canaries site. The latter has already been dismantled so that it can be refurbished before shipment next year. The UK Science Research Council, the body involved in the setting up and funding of the observatory, hopes to place a contract for building the domes to house the telescopes this summer.

The UK also has plans for a $4.2 \mathrm{~m}$ diameter telescope, the largest likely to be built on the site. Although this is only in the design phase and has not yet received the official goahead, an order for its mirror blank has already been placed in the US. Even if approval and funds for the whole telescope were given now, however, it would be at least 1984 before it could come into operation. The total cost of the new observatory to the UK, according to Professor Smith, could be about $£ 2.5$ million for the $1 \mathrm{~m}$ telescope, $£ 8$ million for moving and refurbishing the INT and in excess of $£ 10$ million for the $4.2 \mathrm{~m}$ telescope.

Sweden's and Denmark's contributions will not be so great. Sweden is planning on transferring, almost immediately, a $16 \mathrm{~m}$-high solar tower and a $60 \mathrm{~cm}$ diameter stellar Cassegrain telescope 
to the new observatory. It plans to move its $1.1 \mathrm{~m}$ Schmidt telescope in two years time. Denmark will collaborate with the RGO over a meridian circle.

In addition to the intergovernmental agreement, two other types of agreement were signed last weekend. One is between the UK Science Research Council, the Swedish Academy of Sciences, the Danish Research Administration and the Spanish Consejo Superior de Investigaciones Cientificas. It lays down the details of how the observatory will be used and stipulates the setting up of an international scientific committee to regulate its operation. Each country will be in sole control of $75 \%$ of its own telescopes' time. Spain will be entitled to $20 \%$ of each telescopes' time and the remaining $5 \%$ will be for use by any other country with a stake in the observatory. The UK is also to provide two places each year for Spanish astronomers at British universities, up to four places at the RGO and training at the Canaries observatory. The other agreement, between the Swedish, Danish and British research agencies and the Institute for Astrophysics Research on the Canary Islands, deals with the details of establishing the observatory.

With the opening of the new observatory, most British optical astronomy will move to the Canary Islands. The established centres of optical astronomy in the UK such as the RGO, can adapt to this change, says Professor Smith, by taking leading roles in the management of overseas telescopes, the building and designing of new equipment and in the handling of data from telescopes and spacecraft. In particular, he would like to see the establishment of about a dozen centres for analysing astronomical data with the RGO acting as coordinator. If the SRC were to establish such centres, he says, the UK would be in a good position to act as a data analysis centre for European astronomers using the joint ESA/NASA Space Telescope in the late 1980 s.

Judy Redfearn

\section{How the Soviets view exchanges...}

"SOVIET-UK scientific contacts are, in general, much worse than 15 years ago, and $I$ am affraid this is mostly the fault of Britain". So Professor Andrei Kapitsa, de facto science spokesman of the USSR National Exhibition at Earls Court, London, told Nature.

"There are links and agreements", Kapitsa went on, "but somehow they don't work out very well. They can, of course, be improved by mutual efforts, exchanges of publications and mutual experiments, especially in space".

Professor Kapitsa, a geographer working on remote sensing of the environment from space satellites, has perhaps a personal interest in drawing Britain into joint space experiments with the Soviet Union-he was born in England. Moreover, he asserted more than once that the idea of scientific exchange as a one-way flow of information is "absurd"; the idea of the exhibition, he suggested, is to show British scientists and engineers what the USSR has to offer them.

One way of disseminating such information, he explained, was the "Days of Soviet Science and Technology" organised in conjunction with the exhibition. A party of "20 leading Soviet scientists, sponsored by the Royal Society" will lecture in various British universities. This was the first time that such "days" had been organised in Britain, although they had been held in France, Germany, the Comecon countries, he said. (Subsequent inquiries, incidentally, reduced the total number of the party to 11 , with the Royal Society being responsible only for three, the remainder, medical personnel, coal and oil technologists, Deputy Minister of Power Sapozhnikov, etc., being cared for by the appropriate professional bodies.)

One purpose of these "days", Kapitsa explained, was to explore the possibility of joint research programmes. His ideas on how exchange should be conducted are firm and somewhat paternalistic.
Exchange of top scientists for short visits would be followed by long-term exchanges of the younger generation "to work under the older ones". When challenged that in the past long-term exchange places were sometimes not filled from the British side, since it was virtually impossible for interested young scientists to find out what individual Soviet institutes had to offer, he merely commented: "But that is what a joint programme is for. The exchange of top scientists provides the necessary information!"

To the suggestion that the flow of such information would be increased if it were made easier for young Soviet scientists to attend international conferences, Kapitsa gave a diplomatic "no". Young people's papers were often not up to standard, and (he implied) could not therefore represent Soviet science. "All they want is an excuse to travel abroad". The American idea that only the younger generation was capable of fruitful scientific ideas was "absolutely stupid", he added. His own father, Nobel laureate Petr Kapitsa, was still doing valuable work in his mid-eighties.

$\mathrm{He}$ did admit, however, that the Royal Society and the Soviet Academy. partners in the exchange agreement, did not always operate in the same manner, and made it quite clear which method he thought better. "The Royal Society", he said, "is a society, but the Academy of Sciences is a working board, a research board!"

- Dr R. W. Keay, executive secretary of the Royal Society, comments: "In September 1977, Lord Todd, president of the Royal Society and Academician Anatolii Aleksandrov, president of the Soviet Academy, signed a new exchange agreement, replacing the old rigid system of short-term senior and long-term junior visits by a more flexible arrangement of 49 personmonths per year in both directions. Since then the number of exchange visits has virtually doubled."

\section{-.. and what they've got to share}

KAPITSA's assertion that the West has much to gain from the maintenance and expansion of exchanges with the Soviet Union reiterates the message of several recent quasi-official Soviet statements. Last month, a lengthy Pravda article signed by five members of the Soviet Academy of Sciences (including two vice-presidents and the chief academic secretary) asserted that recent campaigns in the US to sever or suspend scientific contacts with the Soviet Union on human rights grounds are bound to fail and can have no effect on the progress of Soviet science. An impressive list of Soviet contributions to joint research projects was cited in support.

Last week, Academician Viktor Ambartsumyan, speaking on the North American service of Moscow radio took up the story. While not returning to the Stalinist stance of claiming all discoveries for the Soviet Union, Ambartsumyan claimed that the discovery of the ring of Jupiter by the Voyager mission was not the "complete surprise" claimed in the Western press; a certain Professor Chashlavskii of Kiev University had predicted it in 1960. The US media, he said, consistently play down the achievements of Soviet science, so as to present exchange programmes as one-sided.

Further, certain US scientists "who probably do not have much political experience", have been "manipulated" into signing a letter making Soviet-US scientific contacts dependent on the fate of "two persons who have been tried and convicted by Soviet courts". 